\title{
PRAKTIK PEMBAGIAN HARTA GONO-GINI (Studi Pandangan Ulama Aceh Singkil)
}

\author{
Ali Sibra Malisi \\ Program Pasacasarjana Al-Ahwal Al-Syakhsiyah UIN Maliki Malang \\ Jalan Gajayana No. 50 Malang. Telp. 081360979790. \\ email: Malisibra@yahoo.com
}

\begin{abstract}
Marriage is a religious tradition of the Prophet and a devotion for people who are ready both physically and mentally. There is a holy bond in a marriage that must be kept by the bride and the groom. The marriage also emerges a possessing of the wealth together that must be divided equally if the one is dies. This is called the Joint property (gono-gini). The joint property (gono-gini) was only belong to the groom if bride dies, where commonly was owned to the both. But the reality, the joint property was not necessarily belong to the both when one died. This was what happened in the community of Aceh Singkil. This was what makes the researcher interested to research them. This study sought to reveal the view of Singkil's society about the Joint property (gono-gini). This study used an observation and interview in obtaining the accurate and reliable data. In Aceh Singkil, the joint property (gono-gini) would not be divided if the bride died and would be divided when groom died. This Singkil's view based on the reason of worry that if the bride would be left by the remarried husband, the joint property held by her new husband, while if the husband left by his wife, the joint property would not be undistributed, because he has a responsibility towards his children. This view could be concluded that the common law greatly affected the distribution of matrimonial property (Gono-gini).

Pernikahan adalah sunnah Rasul dan merupakan ibadah bagi yang siap secara jasmani dan rohani. Harus dipahami dibalik ikatan pernikahan ada ikatan yang mengikat antara kedua mempelai. Disamping itu, ada beberapa hal yang harus dijaga bersama. Salah satunya adalah harta bersama. Harta bersama
\end{abstract}


(gono-gini) seolah-olah hanya milik mempelai laki-laki jika mempelai wanita meninggal dunia. padahal hakikatnya harta bersama adalah milik bersama. Namun realitanya harta bersama tidak serta merta menjadi milik bersama ketika salah seorang meninggal dunia. hal inilah yang terjadi di masyarakat Aceh, tepatnya Aceh bagian Singkil. Inilah yang membuat peneliti tertarik untuk menelitinya. Penelitian ini berusaha mengungkapkan bagaimana pembagian harta gono-gini dalam pandangan masyarakat Aceh Singkil. Penelitian ini menggunakan metode observasi dan wawancara guna mendapatkan informasi yang akurat dan dapat dipertanggung jawabkan. Harta bersama (gono-gini) tidak mesti dibagikan jika mempelai wanita meninggal dunia. Jika yang terjadi adalah sebaliknya, maka harta bersama harus dibagikan. Keyakinan ini bertahan lama sampai sekarang dikarenakan oleh pandangan bahwa mempelai wanita jika ditinggal oleh suami akan menikah lagi, ditakutkan harta bersama dikuasai oleh suami barunya, sementara jika suami ditinggal oleh istri, harta tidak dibagikan sebab masih mempunyai tanggung jawab terhadap anak-anak mereka. Melihat pandangan diatas maka dapat disimpulkan bahwa hukum adat sangat mempengaruhi proses pembagian harta bersama (gono-gini). Dan minimnya peran ulama dalam pembagian harta bersama (gono-gini).

Key words: marriage, joint property (gono-gini), ulama singkil

\section{Pedahuluan}

Islam sebagai agama memerintahkan penganutnya untuk mengikuti sunnah Rasulnya. Salah satu sunnah Rasul yang harus diikuti adalah menikah bagi yang mampu jasmaniah maupun rohaniah. Prinsip pernikahan adalah membentuk keluarga atau rumah tangga yang sakinah,mawadddah wa rahmah dunia dan akhirat nanti. Meskipun demikian keluarga dalam konteks kedunian bukanlah suatu yang abadi. Artinya keluarga memiliki awal dan akhir. Berakhirnya suatu keluarga dikarenakan beberapa faktor, diantaranya terjadinya perceraian, hilang salah satu pasangan dalam kurun waktu yang lama dan meninggal salah satu pasangan. Disamping itu pernikahan merupakan salah satu penyebab terjadinya harta bersama. Dengan adanya harta bersama, tentunya mengandung prinsip yang lain, yaitu pembagian harta.

Perceraian baik cerai mati atau cerai hidup mengandung berbagai akibat hukum. Salah satunya berkaitan dengan harta bersama atau harta gono gini. Harta bersama atau harta gono gini ada ketika perkawinan berlangsung, sedangkan harta bawaan yang diperoleh sebelum berlangsungnya pernikahan. Bila pernikahan terputus diakibatkan meninggalnya salah satu pasangan maka hak-hak dan kewajibannya diambil alih oleh keturunannya (Prodjodikoro, 1993: 18). Meninggalnya seseorang tidak berakibatkan hilangnya hubungan 
antara keluarga (Ash Shiddieqy, 2010: 22).

Harta bersama atau gono gini tidak mudah untuk mengetahuinya sebab mampir semua masyarakat Indonesia tidak membedakan harta bersama dengan harta bawaan (Hadikusuma, 1990: 56). Oleh karena itulah ketika keluarga putus sangat susah memisahkan harta bawaab dan harta gono gini. Hal ini diakibatkan oleh minimnya pemahaman masyarakat tentang pentingnya hukum yang mengatur harta kepemilikan.

Masyarakat Aceh Singkil misalnya, ketika seorang istri meninggal dunia maka harta warisan maupun harta gono gini tidak dibagikan. Namun akan beda hasilnya jika seoang suami yang meninggal dunia, maka harta waris akan dibagikan kepada ahli waris. Adapun harta waris yang dibagikan adalah harta secara keseluruhan baik sebelum maupun sesudah menikah. Jadi seolah-olah seorang istri tidak memiliki harta. Atas dasar inilah penulis ingin membahasnya. Tentunya pembahasan ini sesuai dengan kadar keilmuan yang dimiliki oleh penulis.

\section{Pengertian Harta Gono-Gini}

Pernikahan merupakan babak pertama adanya harta bersama. Adanya harta bersama berawal dari kesepakatan antara kedua mempelai suami istri. Harta bersama atau harta gono gini salah satu dari sekian harta yang dimiliki seseorang disamping milik pribadi. Harta gono gini artinya harta bersama yang dimiliki antara suami dengan istri ditandai dengan kesepakatan dalam pernikahan. Harta memiliki peran yang vital dalam kehidupan sehari-hari. Tidak jarang status sosial dinilai dari harta, semakin banyak harta yang dimiliki maka semakin tinggi pula status sosial seseorang dalam masyarakat. Selain itu harta berfungsi untuk mencukupi kebutuhan sehari-hari. Jadi harta memiliki peranan penting dalam roda kehidupan seseorang. Akan tetapi masih banyak orang kurang mengerti akan hukum yang mengatur tentang harta.

Kurangnya pemahaman atau bahkan ketidakpahaman tentang hukum yang mengatur harta bersama atau harta gono-gini akan mempersulit seseorang dalam memberdaya gunakan harta tersebut secara baik dan benar tentunya pada tempat yang tepat. Oleh karena itulah perlu kiranya dijelaskan akan pengertian tentang harta gono gini atau harta bersama.

Harta bersama dalam kamus besar Indonesia terdiri dari dua kata yaitu harta dan bersama, harta artinya barang-barang, baik yang berwujud maupun tidak berwujud yang mengandung nilai didalamnya. Jadi harta bersama adalah harta yang diberdaya gunakan secara bersama-sama demi kepentingan bersama 
(Pusat Pembinaan dan Pengembangan Bahasa Departemen Pendidikan dan Kebudayaan, 1995: 342).

Pendapat lain menyebutkan bahwa harta gono gini adalah harta kekayaan yang didapatkan selama ikatan pernikahan terjalin dan diluar harta waris dan hadiah. Dengan artian bahwa harta yang didapat terjalinnya ikatan pernikahan baik yang didapat secara bersama maupun sendiri-sendiri (Thalib, 1986: 89). Pendapat Sayuti Thalib diperkuat dengan Kompilasi Hukum Islam, KUH Perdata, dan Undang-Undang 1 tahun 1974 pasal 35 bab VII tentang harta benda dalam perkawinan sebagai berikut:

1. Harta benda yang diperoleh selama perkawinan menjadi harta benda bersama.

2. Harta bawaan dari masing-masing suami dan istri dan harta benda yang diperoleh sendiri-sendiri sebagai hadiah dan warisan adalah dibawah penguasaan masing-masing sipenerima pihak lain tidak menentukan.

Konsep harta bersama (gono-gini) dapat ditinjau dari segi ekonomi dan hukum, meskipun keduanya dua tinjauan yang berbeda satu sama lain. Tinjauan dari segi ekonomi menitik beratkan pada nilai manfaat atau kegunaan,sedangkan dari segi hukum menitik beratkan pada aturan hukum yang berlaku (Muhammad, 1994: 9). Lain halnya dengan Abdul Manan bahwa harta bersama (gono-gini) adalah harta yang diperoleh selama ikatan perkawinan berlangsung, tanpa mempersoalkan terdaftar atas nama siapa (Manan, 1997: 59). Harta gono-gini dalam persfektif hukum disebut dengan harta bersama. Harta gono gini meliputi harta yang bergerak (mobil, motor, saham dan lain-lain) dan harta tetap (tanah,rumah dan lain-lain). Sedangkan warisan, hadiah dan hibah dari orang tua tidak termasuk harta gono gini melainkan harta bawaan (Bahari, 2012: 153).

Dari penjelasan di atas dapat didefinisikan bahwa harta gono gini adalah harta yang diperoleh selama terjadi ikatan perkawinan. Akan tetapi perlu dipahami tidak semua harta yang didapat selama adanya ikatan perkawinan dikatakan sebagai harta bersama. Harta yang didapat akan menjadi harta gono gini ketika ada kesepatakan antara kedua mempelai yaitu suami dan istri. Sementara harta yang diperoleh sebelum terjalinnya ikatan keluarga tidak bisa dikatakan sebagai harta gono gini. Seperti warisan dan hadiah. Hal ini jelas sebagaimana dijelaskan dalam Undang-Undang No.1 tahun 1974, pasal 35 ayat 2 .

Harta bersama adalah harta kekayaan yang diperoleh selama perkawinan 
di luar warisan atau hadiah, dengan kata lain harta bersama adalah harta yang diperoleh atas usaha mereka atau sendiri-sendiri selama masa ikatan perkawinan (Rofiq, 1995: 200). Harta yang ada baik dari suami maupun istri sebelum pernikahan akan tetap menjadi milik pribadi. Harta bawaan adalah milik pribadi baik istri maupun suami. Harta bawaan akan menjadi harta bersama jika dinyatakan akan dimiliki secara bersama sebagai harta gono gini. Undang-Undang No.1 tahun 1974 pasal 35, pasal 36 dan pasal 37 mengatur tentang harta bersama sejak dimulainya ikatan perkawinan dan selama pernikahan berlangsung. Percampuran harta kekayaan antara suami dan istri baik harta tetap maupun bergerak; harta sekarang dan harta yang diperoleh kemudian hari.

Pemahaman akan pencampuran harta sebagai harta bersama didasari oleh keyakinan bahwa perkawinan adalah ikatan lahir batin antara seorang pria dengan seorang perempuan sebagai pasangan suami istri. Dengan harapan membentuk keluarga yang sakinah, mawaddah wa rahmah berdasarkan Ketuhanan Yang Maha Esa. Hal ini berarti terdapat ikatan yang erat antara suami dan istri yaitu meliputi ikatan lahir dan batin. Artinya ikatan suami istri tidak hanya dipahami sebagai ikatan yang berlandaskan materi, melainkan terdapat ikatan yang meliputi ikatan jiwa dan batin, dengan kata lain bersatunya suami istri baik secara materi maupun dalam segi spritual (Bahari, 2012: 154). Harta merupakan salah satu penunjang terciptanya keharmonisan dan kebahagian keluarga. Adanya harta maka akan terpenuhi kebutuhan yang diinginkan. Pernikahan merupakan awal adanya harta bersama, baik itu diperoleh secara individu ataupun diperoleh bersama-sama (Soemiyati, 1999: 102).

Harta bersama dalam Kompilasi Hukum Islam disebut dengan istilah syirkah, yang berarti harta yang diperoleh baik sendiri-sendiri atau bersama suami istri selama dalam ikatan perkawinan berlangsung, tanpa mempersoalkan terdaftar atas nama siapapun. Dalam Kompilasi Hukum Islam pengaturan tentang harta bersama ini, antara lain terdapat pada pasal:

Pasal 85 yang menyatakan harta bersama dalam perkawinan itu tidak menutup kemungkinan adanya harta milik masing-masing suami atau istri.

Pasal 86 ayat (2), harta istri tetap menjadi hak istri dan dikuasai penuh olehnya demikian juga harta suami tetap menjadi hak suami dan dikuasai penuh olehnya.

Pasal 87 ayat (1), harta bawaan dari masing-masing suami dan istri yang diperoleh masing-masing sebagai hadiah atau warisan adalah dibawah penguasaan masing-masing, sepanjang para pihak tidak lain menentukan 
dalam perjanjian perkawinan.

Pasal 87 ayat (2), suami atau istri mempunyai hak sepenuhnya untuk melakukan perbuatan hukum atas harta masing-masing berupa hibah, hadiah sodakah atau lainnya.

Undang-Undang Nomor 1 Tahun 1974 tentang Perkawinan juga mengatur tentang harta kekayan antara lain dalam pasal:

Pasal 35 ayat (1) menyatakan harta benda yang diperoleh sepanjang perkawinan menjadi harta bersama.

Pasal 35 Ayat (2) menyebutkan harta bawaan dari masing-masing suami atau istri dan harta benda yang diperoleh masing-masing sebagai hadiah atau warisan adalah di bawah penguasan masingmasing sepanjang para pihak tidak menentukan lain.

Pasal 36 ayat (1) menyebutkan harta bersama suami dan istri dapat bertindak atas persetujuan kedua belah pihak.

Pasal 37 ayat (1) yaitu bilamana perkawinan putus karenma perceraian maka harta bersama diatur menurut hukumnya masing-masing.

Merujuk pada kedua peraturan di atas, yakni Kompilasi Hukum Islam dan Undang-Undang Nomor 1 Tahun 1974 tentang Perkawinan dapat disimpulkan bahwa kedua aturan tersebut sejalan dalam pengaturan tentang harta bersama. Artinya ada kesamaan antara Komplikasi Hukum Islam dengan Undang-Undang Nomor 1 tahun 1974 dalam mengatur harta bersama dalam ikatan perkawinan.

\section{Macam-Macam Harta Gono-Gini}

Asal usul harta yang diperoleh suami istri dibagi menjadi empat sumber yaitu: 1). Harta hibah dan harta warisan yang diperoleh dari salah satu, baik dari suami maupun istri. 2). Harta hasil usaha sendiri sebelum adanya ikatan pernikahan. 3).Harta yang diperoleh pada saat perkawinan atau karena perkawinan. 4). Harta yang diperoleh selama perkawinan kecuali harta warisan dan hibah yang diperoleh salah satu dari suami istri (Huri, 2012: 29).

Penggolongan harta menjadi dua golongan yaitu harta bersama yang dimiliki dan dikuasai bersama, harta masing-masing yang dimiliki dan dikuasai oleh masing-masing dari suami istri (Syah, 1984: 148). Oleh kerena itu perlu kiranya dipertegas lagi tentang harta bersama, apakah semua harta yang didapat selama ikatan pernikahan antara suami istri merupakan harta bersama?.

Keempat sumber harta yang didapat sebagaimana dijelaskan di atas dapat disebut dengan harta kekayaan. Konsep harta kekayaan sebagaimana 
dikemukakan pada uraian sebelumnya dapat ditinjau dari segi ekonomi dan hukum yang keduanya ada hubungan satu sama lain. Tinjauan ekonomi menitikberatkan pada nilai kegunaan sedangkan dari hukum menitikberatkan pada aturan hukum yang mengatur.Harta bersama yang dimiliki suami istri dari segi hukum diatur dalam Undang-Undang Perkawinan No. 1 Tahun 1974 pasal 35 dan 36 sebagai berikut: Pasal 35: 1). Harta benda yang diperoleh selama perkainan menjadi harta benda bersama. 2). Harta bawaan dari suami dan istri dan harta benda yang diperoleh masing-masing sebagai hadiah atau warisan berada di bawah penguasaan masing-masing penerima, para pihak lain tidak menentukan. Sementara pasal 36: 1). Mengenai harta bersama suami istri dapat bertindak atas persetujuan kedua belah pihak. 2). Harta bawaan suami dan istri mempunyai hak sepenuhnya untuk melakukan perbuatan hukum terhadap harta bendanya.

Harta bersama dalam Kompilasi Hukum Islam diatur dalam Bab XII tentang harta kekayaan dalam perkawinan dalam pasal 85 sampai dengan pasal 97. Sementara pasal 85 Kompilasi Hukum Islam menyatakan bahwa: adanya harta bersama dalam perkawinan itu tidak menutup kemungkinan adanya harta milik masing-masing usami atau istri. Adapun jenis-jenis harta bersama dalam pasal 91 Kompilasi Hukum Islam adalah sebagai sebagai berikut:

1. Harta bersama sebagaimana tersebut dalam pasal 85 di atas dapat berupa benda berwujud atau tidak berwujud.

2. Harta bersama yang berwujud dapat meliputi benda tidak bergerak, benda bergerak, dan surat-surat berharga.

3. Harta bersama yang tidak berwujud dapat berupa hak maupun kewajiban.

4. Harta bersama dapat dijadikan sebagai barang jaminan oleh salah satu pihak atas persetujuan pihak lainnya.

Memperhatikan pasal-pasal di atas bahwa yang dianggap sebagai harta bersama adalah berupa benda milik suami istri yang mempunyai nilai ekonomi dan nilai hukum, yaitu nilai mempunyai nilai kegunaan dan ada aturan hukum yang mengatur. Harta bersama dapat berupa benda berwujud yang meliputi benda bergerak dan tidak bergerak serta harta bersama dapat berbentuk surat-surat berharga dan harta bersama dapat berupa benda tidak berwujud berupa hak dan kewajiban.

Benda dalam Literatur Hukum adalah terjemahan dari istilah bahasa Belanda Zaak, barang adalah terjemahan dari goog, dan hak adalah terjemahand dari recht. Menurut pasal 499 KUHP perdata, pengertian benda meliputi 
barang dan hak, barang adalah benda berwujud sedangkan hak adalah benda tak berwujud pada benda melekat suatu hak. Setiap pemilik benda adalah juga pemilik hak atas bendanya itu. Hak atas benda milik tersebut hak milik yang disingkat dengan milik saja (Muhammad, 1994: 10). Jadi harta bersama adalah harta milik suami maupun istri baik berupa hak dan kewajiban yang harus ditanggung oleh suami istri.

Pasal 35 UU No. 1 Tahun 1974, menjelaskan bahwa harta bersama suami istri hanyalah meliputi harta-harta yang diperoleh suami istri sepanjang terjalinya perkawinan. Artinya, harta yang diperoleh selama adanya pernikahan, yaitu mulai peresmian perkawinan hingga perkawinan tersebut putus, baik terputus karena kematian salah seorang diantar mereka (cerai mati) ataupun disebabkan perceraian (cerai hidup). Dengan demikian, harta yang dimiliki sebelum terjalinnya ikatan pernikahan tidak termasuk harta bersama. Ketentuan di atas tidak menyebutkan darimana atau dari siapa harta tersebut berasal, sehingga boleh disimpulkan, bahwa harta bersama adalah hasil yang diperoleh suami maupun istri serta hasil yang diperoleh dari harta pribadi suami maupun istri, sekalipun harta pokoknya tidak termasuk dalam harta bersama, jika semuanya diperoleh sepanjang perkawinan. Jadi, untung rugi merupakan tanggungan dari harta bersama,hutang misalnya (Bahari, 2012: 154).

Kompilasi Hukum Islam Pasal 91 menjelaskan bahwa wujud harta bersama adalah sebagai berikut, 1). Harta bersama sebagaimana disebutkan dalam Pasal 85 dapat berupa benda berwujud atau tidak berwujud. 2). Harta bersama yang berwujud dapat meliputi benda bergerak, tidak bergerak dan surat-surat berharga lainnya. 3). Harta bersama yang tidak berwujud dapat berupa hak maupun kewajiban. 4). Harta bersama dapat dijadikan sebagai barang jaminan oleh salah satu pihak atas persetujuan pihak lain (Manan, 1997: 75).

Kompilasi Hukum Islam pasal 92 berbunyi bahwa suami atau istri tanpa persetujuan pihak lain tidak diperbolehkan menjual atau memindahkan harta bersama. Suami atau istri mempunyai tanggung jawab yang sama terhadap harta bersama. Harta gono gini akan dibagi sama rata jika ikatan pernikahan terputus disebabkan oleh kematian salah satu diantara kedua dan perceraian dan putusan pengadilan untuk membagi harta bersama tersebut.

Harta bersama dibagi dalam 3 (tiga) kelompok sebagai berikut (Thalib, 1986: 83):

Harta bersama dapat digolongkan menjadi 3 golongan jika dilihat dari asal usul harta suami istri yaitu: 
1. Harta suami atau istri sebelum perkawinan adalah harta bawaan atau dapat dimiliki sendiri-senndiri.

2. Harta yang diperoleh sepanjang perkawinan diluar usaha bersama seperti hibah, wasiat atau warisan adalah milik masing-masing.

3. Harta yang diperoleh sepanjang perkawinan, dengan cara sendirisendiri maupun bersama-sama merupakan harta pencaria atau harta bersama.

4. Harta bersama dari sudut pandang kegunaan atau manfaat, maka harta bersama digunakan untuk:

5. Pembiayaan rumah tangga yang mencakup kebutuhan keluarga dan biaya sekolah anak-anak.

6. Harta kekayaan yang lain.

7. Harta bersama dilihat dari sudut pandang hubungan harta dengan perorangan dalam masyarakat, harta itu akan berupa:

8. Harta milik bersama.

9. Harta milik pribadi tapi terikat pada keluarga.

10. Harta milik pribadi tanpa terikat orang lain.

11. Harta kekayaan yang dapat dibagi adalah harta kekayaan yang diperoleh selama adanya ikatan pernikahan. Adapun penyebab terbaginya harta bersama yaitu terjadinya perceraian, kematian salah satu pasangan ataupun hasil putusan pengadilan. Perlu dipahami penetapan harta bersama dalam suatu perkawinan adalah penting untuk kemaslahatan bersama, dengan harapan penguasaan dan pembagian harta bersama secara adil. Pembagian harta bersama dilakukan ketika putusnya ikatan perkawinan. Harta gono gini dikuasai secara bersama-sama. Tindakan terhadap harta bersama harus disepakati oleh suami ataupun istri. Jika perkawinan putus maka harta bersama akan dibagi sama rata antara suami dan istri.

\section{Pembagian Harta Gono-Gini}

Al Quran dan Hadits nabi merupakan landasan utama sebagai sumber hukum perkawinan di negara Islam ataupun negara yang mayoritas pemeluk Islam. Namun, dalam praktiknya ada perbedaan dalam penerapannya. Perbedaan mazhab dan ketidaksamaan sistem hukum yang dianut negara adalah faktor penyebab terjadinya perbedaan dalam penerapan hukum (Suma, 2005: 203). Pada umumnya di negara-negara Islam, harta bersama tidak dipermasalahkan, terlebih-lebih dimasukkan kedalam Undang-Undang. Sebab negara menganut 
mazhab yang mengakui bahwa suami mempunyai kewajiban memberi nafkah kepada istri, mulai dari kebutuhan pokok, pembantu rumah tangga dan sebagainya (Mugniyah, 2010: 401). Dengan demikian istri hanya mengurusi rumah tangga serta menjaga anak-anak. Lain halnya di Indonesia, istri ikut membantu kebutuhan rumah tangga, mulai mencuci, belanja ke pasar dan menjaga anak-anak, bahkan ikut mencari nafkah demi kebutuhan keluarga. Sehingga seorang istri terpaksa bekerja sampai larut malam demi menutupi kebutuhan rumah tangga.

Melihat penjelasan di atas,bahwa harta yang diperoleh selama ikatan perikahan, antara suami dan istri mempunyai hak yang sama terhadap harta bersama.halini jelas tercantum dalam peraturan perundang-undangan hukum keluarga Indonesia. Perlu dipahami peraturan perundangan sampai menjadi sebuah Undang-Undang tentunya memerlukan pemikira yang dalam. Hal ini telah dilakukan para ulama secara ijtihad. Inilah konsep awal mengapa terjadi perbedaan tentang masalah harta gono gini antara Indonesia dengan Negara Islam lainnya terutama dengan Negara-Negara Arab.

Undang-Undang nomor 1 tahun 1974 pasal 35 ayat 1 menegaskan bahwa harta benda yang diperoleh selama perkawinan adalah harta bersama, dengan kata lain harta gono gini atau sirkah terbentuk sejak tanggal disahkannya perkawinan sampai perkawinan putus. Suatu barang atau benda menjadi harta bersama atau tidaknya ditentukan ketika terjadinya perkawinan antara mempelai laki-laki dan mempelai wanita. Warisan, hibah dan hadiah yang diterima oleh satu pihak akan menjadi milik pribadi dan tidak termasuk harta bersama atau gono gini.

Komplikasi Hukum Islam pasal 1 sub f jo dan pasal 85 menyebutkan bahwa harta bersama adalahb harta yang diperoleh sepanjang perkawinan, harta milik suami ataupun istri yang terdaftar. Akan tetapi akan menjadi miliki pribadi apabila harta yang dipergunakan untuk membeli suatu barang menggunakan harta pribadi suami atau istri. Dengan kata lain membeli barang dengan harta pribadi adalah milik pribadi. Suami istri bisa memiliki harta gono gini setelah terjadi perceraian, dengan syarat bahwa uang yang dipergunakan untuk membeli barang berasal dari harta bersama semasa pernikahan dahulu. Jadi harta bersama pasca perceraian akan dibagi sama rata dan adil.

Undang-Undang nomor 1 tahun 1974 pasal 37 tentang Perkawinan menjelaskan "jika perkawinan putus karena perceraian, harta bersama diatur menurut hukumnya masing-masing”. Adapun yang dimaksud dengan hukum masing-masing ditegaskan dalam penjelasan pasal 37 ialah "hukum 
agama,hukum adat dan hukum-hukum lainnya". Jika dalam perkawinan ada perjanjian perkawinan antara suami istri maka pembagiannya mengacu kepada perjanjian yang dibuat antara suami istri. Namun perlu dicermati jika begitu yang terjadi, harta bersama atau gono gini kapan ditentukan pembagiannya. Harta bersama atau gono gini terkait dengan perkawinan. Perkawinan merupakan langkah pertama adanya harta bersama atau harta gono gini.

Harta bersama atau harta gono gini tidak dipersamalahkan selama kehidupan keluarga atau kehidupan suami istri harmonis. Pembagian harta gono gini terjadi ketika dalam suatu rumah tangga terjadi persilihan yang mengarah pada perceraian antara suami istri. Macam-macam perceraian dalam kitab fiqh maupun dalam Undang-Undang yaitu cerai talak, cerai gugat dan cerai karena kematian (Damanhuri, 2012 32).

Undang-Undang omor 1 tahun 1974 pasal 37 tidak menegaskan berapa bagian masing-masing antara suami istri, baik cerai mati maupun cerai hidup, lainhalnya dalam Komplikasi Hukum Islam pasal 96 dan pasal 97 mengatur tentang pembagian syirkah baik cerai mati maupun cerai hidup, masing-masing suami istri mendapat setengah dari harta bersama sepanjang tidak ditentukan dalam perjanjian perkawinan. Adapun bunyi Komplikasi Hukum Islam pasal 96 adalah sebagai berikut a). Apabila terjadi cerai mati maka setengah dari harta bersama menjadi hak pasangan yang hidup lebih lama, b). Pembagian harta bersama bagi suami atau istri bilamana istri atau suaminya hilang harus ditangguhkan sampai adanya kepastian atau meninggalnya secara hukum atas dasar keputusan Pengadilan Agama. Komplikasi Hukum Islam pasal 97 menyatakan bahwa janda atau duda yag cerai hidup, kedua belah pihak berhak mendapat seperdua dari harta bersama sepanjang tidak ditentukan dalam perjanjian perkawinan.

Melihat penjelasan dari Komplikasi Hukum Islam pasal 96 dan pasal 97 dapat dikatakan bahwa harta bersama atau harta gono gini ataupun syirkah dibagi sama rata atau seperdua bagian antara suami dan istri. Proses pembagian harta bersama dapat dilakukan secara kekeluargaan ataupun dengan bantuan pengadilan.

\section{Harta Gono-Gini dalam Hukum Islam}

Al Quran dan Hadist secara eksplisit tidak membicarakan tentang harta bersama atau harta gono gini. Pembahasan tentang harta bersama atau harta gono gini terdapat dalam kitab-kitab fiqh dengan pembahasan syirkah atau syarikah. Meskipun Al Quran tidak membicarakan harta bersama secara 
eksplisit, sebagaian ulama bahwa QS. an Nisa: 32, membicarakan tentang harta bersama. Kira-kira artinya sebagai berikut, jangalah kamu iri hati karena Allah SWT, melebihkan sebagian kamu daripada yang lain, untuk laki-laki ada bagian dari usaha yang dikerjakannya, dan untuk perempuan ada bagian daripada usaha yag dikerjakannya.

Perbedaan pendapat antara pakar hukum Islam di Indonesia tak terelakkan dalam menentukan dasar hukum harta bersama atau harta gono gini. Sebagian berpendapat bahwa al Quran tidak mengaturya, oleh karena itu urusan penentuan dasar hukum harta bersama diserahkan pada ahlinya. Pendapat ini dikemukakan oleh Hajairin, Anwar Haryono dan Abdoel Rooef. Namun sebagian lain berpendapat adalah aneh jika Islam tidak mengatur tentang harta gono gini. Sebab hal-hal kecil saja diatur secara terperinci dan ditentukan kadar hukumnya. Bahkan tidak ada satupun perkara yang tidak diatur dalam ruang lingkup pembahasan hukum Islam. Jika al Quran tidak mendefinisikan secara eksplisit maka penjelsannya ada dalam hadist. Pendapat ini dikemukakan oleh Jafizham (Jafizham, 1977: 119).

Ulama-ulama terdahu sudah menyusun kitab-kitab dibidang hukum yang kemudian hari dikenal dengan kitab fiqh. Pembahasan dalam kitab fiqh dibagi menjadi empat bagian yaitu:

1. Rubu' ibadah. Buku ini menjelaskan tentang ibadah diantaranya adalah sholat, puasa, zakat dan haji.

2. Rubu' mu'amalah. Buku ini menjelaskan tentang maslah yang berkaitan dengan hokum kebendaan, hukum perikatan dan hukum dagang.

3. Rubu' munakahat. Buku ini menjelaskan tentang masalah pernikahan, perceraian dan yang berhubungan dengan itu.

4. Rubu' jinayah. Buku ini menjelaskan tentang hukum pidana.

Merujuk pada penjelasan diatas, harta bersama atau gono gini seharusnya ada dalam pembahasan rubu' mu'amalah, akan tetapi tidak ditemukan penjelasan yang khusus membahasnya. Hal ini dimungkinkan adat Arab yang tidak mengenal adanya harta bersama antara suami istri. Akan tetapi adat arab mengenal istilah syirkah atau syarikah. Dengan kata lain adat arab mengenal istilah perkongsian. Istilah syarikat dalam bahasa Indonesia saat ini berasal dari bahasa Arab, sebab dalam bahasa Arab kata syarikat merupakan bentuk jamak. Jadi masalah harta bersama antara suami dan istri termasuk dalam perkara perkongsian atau syarikah. Secara etimologi syarikah berarti 
percampuran suatu harta dengan harta lain sehingga tidak dapat dibedakan lagi satu sama lain. Dengan kata lain, terjadinya penggabungan suatu harta dengan harta lain. Menurut hukum Islam adanya hak dua orang atau lebih terhadap sesuatu (Syah, 1984: 282).

\section{Pembagian Harta Gono-Gini dalam Pandangan Ulama Aceh Singkil}

Pendapat ulama Aceh Singkil diwakili oleh Rasyiduddin (ketua majlis permusyawaratan ulama) terhadap pembagian harta bersama atau harta gono gini beranggapan bahwa pembagian harta bersama sudah jelas disebutkan dalam al Quran. Rasyiduddin mengatakan bahwa pembahasan tentang pembagian harta bersama ayatnya sudah jelas (qat'i). jika seorang suami meninggal dunia, maka istri mendapat seperempat dari harta yang ditinggalkan setelah membayar hutang dan wasiatnya. Dan seorang istri mendapat seperdelapan dari harta yang ditinggalkan oleh suaminya apabila tidak mempunyai anak (keturunan). Sama halnya dengan suami, jika istri meninggal dunia maka suami mendapat setengah dari harta yang ditinggalkan setelah hutang dibayar dan menunaikan wasiatnya. Dan seorang suami mendapatkan bagian dari harta yang ditinggalkan istrinya seperempat apabila tidak mempunyai keturunan (Rasyiduddin, interview, 05-02-2013).

Rasyiduddin menjelaskan lebih jauh lagi, bahwa pembagian harta bersama seharusnya melibatkan istri, sebab istri termasuk salah satu ahli waris. Jika tidak memasukkan istri dalam pembagian harta bersama tentunya menyalahi hukum itu sendiri. Kejadian selama ini (Aceh Singkil), tidak sedikit pihak istri yang menerima bagian dari pembagian harta bersama atau harta gono gini. Lebih lanjut lagi Rasyiduddin menjelaskan bahwa ada beberapa faktor penyebab hal ini terjadi diataranya adalah minimnya pengetahuan masyarakat akan hukum. Disamping itu komunikasi antara masyarakat dengan ulama dan orang yang lebih mengetahui hukum.

Penjelasan diatas dapat disimpulkan bahwa ketidak pahaman masyarakat akan hukum diakibatkan oleh jarangnya komunikasi antara ulama setempat dengan masyarakat, selain itu tidak banyak masyarakat yang mengerti hukum. Disamping itu pemangku Majelis Permusyawaratan Ulama Aceh (MPU) tidak sering jemput bola. Hal ini diakui oleh Rasyiduddin sendiri sebagaimana ia mengatakan "Wei, idi enggo jelas khebakken kita akui kesalahan masyarakhat si kukhang mengekhti hukum. Mungkin end ape mekhupaken masuken mi. Kami selaku Majelis Permusyawaratan Ulama Aceh Singkil untuk lebih mempekhhatiken masalah enda masa mi muka". (Ia, itu sudah jelas dan kita akui kesalahan masyarakat yang kurang mengerti hukum. Mungkin ini juga merupakan masukan bagi kami 
sebagai instansi Majelis Permusyawaratan Ulama untuk lebih memperhatikannya di masa-masa yang akan datang).

\section{Simpulan}

Praktik pembagian waris harta gono gini di Kabupaten Aceh Singkil mengabaikan hak istri ketika meninggal dunia disebabkan oleh pengaruh hukum adat yang sudah mengakar di masyarakat, secara umum masyarakat beranggapan demikianlah proses praktik pembagian waris yang benar dan sudah sesuai menurut Islam. Hal ini dilakukan karena masyarakat beranggapan bahwa terhadap harta yang ditinggalkan istri masih ada suami yang bertanggung jawab, dan suami masih mempunyai tanggungan terhadap anak-anak mereka. Sedangkan terhadap harta yang ditinggalkan oleh suami dibagikan tanpa terlebih dahulu memisahkan dari harta bersama karena mereka beranggapan bahwa, ketika suami telah meninggal dunia maka si istri akan menikah lagi dengan orang lain. Mayoritas masyarakat Aceh Singkil ketika harta diserahkan pada istri ditakutkan akan dikuasai oleh suami barunya. Sehingga anak-anak yang mereka tinggalkan, dikhawatirkan akan terbengkalai dan tidak ada yang menanggungjawabi semua kebutuhan hidupnya.

Mayoritas ulama berpandangan bahwa praktik tersebut kurang sesuai dengan ajaran Islam. Sehingga ketika ulama tersebut diminta untuk membantu dalam proses pembagian warisan, ia tetap merujuk kepada ayat-ayat al Quran dan membagikannya sesuai dengan yang ada di ayat tersebut. Sebelum membagikannya terlebih dahulu memisahkan antara harta milik pribadi dan harta gono gini, setelah itu baru dibagikan. Tidak dapat dipungkiri ada beberapa ulama yang berpandangan bahwa istri tidak memiliki harta sebab istri adalah tanggung jawab suami, dan wajib dibiayai. Sehingga istri hanya memelihara harta suami dan anak-anak mereka. Wallaahu a'lam bi al-showaab.

\section{Daftar Pustaka}

Ash-Shiddieqy, Hasbi. 1993. Fiqh Waris: Hukum Pembagian Waris menurut Syari'at Islam, Semarang: Pustaka Rizki Putra.

Bahari, Adib. 2012. Prosedur Gugatan Cerai, Pembagian Harta Gono-Gini, Hak Asuh Anak, Yogyakarta: Pustaka Yustisia.

Damanhuri HR, A. 2012. Segi-Segi Hukum Perjanjian Perkawinan Harta Bersama, Bandung: Mandar Maju.

Jafizham, T. 1997. Persentuhan Hukum di Indonesia dengan Hukum Perkawinan Islam, Medan: Percetakan Mustika. 
Manan, Abdul. 1997. Beberapa Masalah tentang Harta Bersama, Mimbar Hukum No. 33 Th. VIII.

Muhammad, Abdul Kadir. 1994. Hukum Harta Kekayaan, Bandung: Citra Atitya.

Mugniyah, Muhammad Jawad. 2010. Fiqih Limia Mazhab, Terj. Masykur AB. dkk., Jakarta: Lentera.

Prodjodikoro, Wirjono. 1993. Hukum Warisan di Indonesia, Bandung: Sumur Bandung.

Pusat Pembinaan dan Pengembangan Bahasa Departemen Pendidikan dan Kebudayaan, Kamus Besar Bahasa Indonesia, Edisi Kedua, Cet. VII, (Jakarta: Balai Pustaka, 1995).

Rasyidudin, interview: Aceh Singkil, 5 Pebruari 2013

Rofiq, Ahmad. 1995. Hukum Islam Di Indonesia, Jakarta: PT Raja Grafindo Persada.

Soermiyati, 1999. Hukum Perkawinan Islam dan Undang-undang Perkawinan, Yogyakarta: Liberty.

Suma, Muhammad Amin. 2005. Hukum Keluarga Islam di Dunia Islam, Jakarta: PT Raja Grafindo Persada.

Syah, Ismail Muhammad. 1984. Pencaharian Bersama Istri di Aceh Ditinjau dari Sudut Undang-Undang Perkawinan No. 1 Tahun 1974 tentang Perkawinan dan Hukum Islam, Disertasi dalam Ilmu Hukum, Medan: Universitas Sumatera Utara.

Thalib, Sayuti. 1986. Hukum Keluarga Indonesia, Jakarta: UI Press.Abdul 